Abstracta Iranicacta Iranica

Revue bibliographique pour le domaine irano-aryen

Volume 28 | 2007

Comptes rendus des publications de 2005

\title{
«Intégration régionale en Asie centrale ». CEMOTI, 39-40, 2005, pp. 53-72.
}

\section{Bernard Hourcade}

\section{OpenEdition}

1 Journals

\section{Édition électronique}

URL : http://journals.openedition.org/abstractairanica/20151

DOI : 10.4000/abstractairanica.20151

ISSN : 1961-960X

Éditeur :

CNRS (UMR 7528 Mondes iraniens et indiens), Éditions de l'IFRI

\section{Édition imprimée}

Date de publication : 15 mai 2007

ISSN : 0240-8910

Référence électronique

Bernard Hourcade, « «Intégration régionale en Asie centrale ». CEMOTI, 39-40, 2005, pp. 53-72. », Abstracta Iranica [En ligne], Volume 28 | 2007, document 480, mis en ligne le 18 septembre 2007, consulté le 25 septembre 2020. URL : http://journals.openedition.org/abstractairanica/20151 ; DOI : https://doi.org/10.4000/abstractairanica.20151

Ce document a été généré automatiquement le 25 septembre 2020.

Tous droits réservés 


\section{«Intégration régionale en Asie centrale ». CEMOTI, 39-40, 2005, pp.} 53-72.

\section{Bernard Hourcade}

Cette étude porte principalement sur l'intégration économique de la région depuis la chute de l'URSS, avec notamment des données sur les échanges au sein de l'ECO (Organisation de Coopération Économique) et de l'ocs (Organisation de coopération de Shanghai), montrant les faibles relations entre ces pays et les luttes d'influence des grands pays voisins (Turquie, Iran, Russie, Chine).

\section{INDEX}

Thèmes : 13.3. Asie centrale

\section{AUTEURS}

\section{BERNARD HOURCADE}

CNRS / Mondes iranien et indien - Paris 